\title{
Radiocarbon dating of alpine ice cores with the dissolved organic carbon (DOC) fraction
}

\author{
Ling Fang ${ }^{1,2,3}$, Theo M. Jenk ${ }^{1,3}$, Thomas Singer ${ }^{1,2,3}$, Shugui Hou ${ }^{4,5}$, and Margit Schwikowski ${ }^{1,2,3}$ \\ ${ }^{1}$ Laboratory for Environmental Chemistry, Paul Scherrer Institute, 5232 Villigen PSI, Switzerland \\ ${ }^{2}$ Department of Chemistry and Biochemistry, University of Bern, 3012 Bern, Switzerland \\ ${ }^{3}$ Oeschger Centre for Climate Change Research, University of Bern, 3012 Bern, Switzerland \\ ${ }^{4}$ School of Geographic and Oceanographic Sciences, Nanjing University, Nanjing, 210023, China \\ ${ }^{5}$ School of Oceanography, Shanghai Jiao Tong University, Shanghai 200240, China
}

Correspondence: Theo M. Jenk (theo.jenk@psi.ch)

Received: 13 August 2020 - Discussion started: 2 September 2020

Revised: 26 January 2021 - Accepted: 8 February 2021 - Published: 26 March 2021

\begin{abstract}
High-alpine glaciers are valuable archives of past climatic and environmental conditions. The interpretation of the preserved signal requires a precise chronology. Radiocarbon $\left({ }^{14} \mathrm{C}\right)$ dating of the water-insoluble organic carbon (WIOC) fraction has become an important dating tool to constrain the age of ice cores from mid-latitude and low-latitude glaciers. However, in some cases this method is restricted by the low WIOC concentration in the ice. In this work, we report first ${ }^{14} \mathrm{C}$ dating results using the dissolved organic carbon (DOC) fraction, which is present at concentrations of at least a factor of 2 higher than the WIOC fraction. We evaluated this new approach by comparison to the established $\mathrm{WIO}^{14} \mathrm{C}$ dating based on parallel ice core sample sections from four different Eurasian glaciers covering an age range of several hundred to around 20000 years; ${ }^{14} \mathrm{C}$ dating of the two fractions yielded comparable ages, with $\mathrm{WIO}^{14} \mathrm{C}$ revealing a slight, barely significant, systematic offset towards older ages comparable in magnitude with the analytical uncertainty. We attribute this offset to two effects of about equal size but opposite in direction: (i) in-situ-produced ${ }^{14} \mathrm{C}$ contributing to the DOC resulting in a bias towards younger ages and (ii) incompletely removed carbonates from particulate mineral dust $\left({ }^{14} \mathrm{C}\right.$-depleted) contributing to the WIOC fraction with a bias towards older ages. The estimated amount of in-situ-produced ${ }^{14} \mathrm{C}$ in the DOC fraction is smaller than the analytical uncertainty for most samples. Nevertheless, under extreme conditions, such as very high altitude and/or low snow accumulation rates, $\mathrm{DO}^{14} \mathrm{C}$ dating results need to be interpreted cautiously. While during DOC extraction the re-
\end{abstract}

moval of inorganic carbon is monitored for completeness, the removal for WIOC samples was so far only assumed to be quantitative, at least for ice samples containing average levels of mineral dust. Here we estimated an average removal efficiency of $98 \pm 2 \%$, resulting in a small offset of the order of the current analytical uncertainty. Future optimization of the removal procedure has the potential to improve the accuracy and precision of $\mathrm{WIO}^{14} \mathrm{C}$ dating. With this study we demonstrate that using the DOC fraction for ${ }^{14} \mathrm{C}$ dating not only is a valuable alternative to the use of WIOC but also benefits from a reduced required ice mass of typically $\sim 250 \mathrm{~g}$ to achieve comparable precision of around \pm 200 years. This approach thus has the potential of pushing radiocarbon dating of ice forward even to remote regions where the carbon content in the ice is particularly low.

\section{Introduction}

For a meaningful interpretation of the recorded palaeoclimate signals in ice cores from glacier archives, an accurate chronology is essential. Annual layer counting, supported by and tied to independent time markers such as the $1963 \mathrm{nu}-$ clear fallout horizon evident by a peak maximum in tritium or other radioisotopes or distinct signals from known volcanic eruptions in the past, is the fundamental and most accurate technique used for ice core dating. However, for ice cores from high-alpine glaciers this approach is limited to a few centuries only because of the exceptionally strong thinning 
of annual layers in the vicinity of the bedrock. Most of the current analytical techniques do not allow high enough sampling resolution for resolving seasonal fluctuations or detecting distinct single events in this depth range. Ice flow models, which are widely used to retrieve full-depth age scales (e.g. Nye, 1963; Bolzan, 1985; Thompson et al., 2006), also fail in the deepest part of high-alpine glaciers due to the assumption of steady-state conditions and the complexity of glacial flow and bedrock geometry limiting realistic modelling of strain rates. Even with 3D models, which require extensive geometrical data, it is highly challenging to simulate a reasonable bottom age (e.g. Licciulli et al., 2020). This emphasizes the need for an absolute dating tool applicable to the oldest bottom parts of cores from these sites.

Radioactive isotopes contained in the ice offer the opportunity to obtain absolute ages of an ice sample. For millennialscale ice cores, ${ }^{14} \mathrm{C}$ dating is the technique of choice. With a half-life of 5370 years, dating in the age range from 250 years to up to 10 half-lives is theoretically possible, covering the time range accessible by alpine glaciers in the vast majority of cases (Uglietti et al., 2016). The ${ }^{14} \mathrm{C}$ dating approach using water-insoluble organic carbon (WIOC) from glacier ice has become a well-established technique for ice core dating, and its accuracy was recently validated (Uglietti et al., 2016). Ice samples from mid- and low-latitude glaciers can now be dated with a reasonable uncertainty of $10 \%-$ $20 \%$. Ice sample masses of $200-800 \mathrm{~g}$ are usually selected to aim for $>10 \mu \mathrm{g}$ carbon for ${ }^{14} \mathrm{C}$ analysis with accelerator mass spectrometry (AMS), whereby the respective mass depends on sample age and organic carbon concentrations (Jenk et al., 2007, 2009; Sigl et al., 2009; Uglietti et al., 2016; Hoffmann et al., 2018). Accordingly, the low WIOC concentration in some glaciers and in polar regions and the related large demands of ice mass put a limit to this application. Concentrations of dissolved organic carbon (DOC) in glacier ice are a factor of 2-8 higher compared to typical WIOC concentrations (Legrand et al., 2007, 2013; May et al., 2013; Fang et al., 2021). Using the DOC fraction for ${ }^{14} \mathrm{C}$ dating could therefore reduce the required amount of ice or, for sample sizes similar to what would be needed for ${ }^{14} \mathrm{C}$ dating by WIOC, improve the achievable analytical (dating) precision, which strongly depends on the absolute carbon mass even for state-of-the-art micro-radiocarbon dating. The underlying hypothesis of applying the DOC fraction for ${ }^{14} \mathrm{C}$ dating is the same as for the $\mathrm{WIO}^{14} \mathrm{C}$ dating approach (Jenk et al., 2006, 2007, 2009). DOC in ice is composed of atmospheric watersoluble organic carbon (WSOC) contained in carbonaceous aerosol particles and organic gases taken up during precipitation (Legrand et al., 2013). WSOC is formed in the atmosphere by oxidation of gases emitted from the biosphere or from anthropogenic sources (Legrand et al., 2013; Fang et al., 2021) and subsequent condensation of the less volatile products. Carbonaceous aerosols transported in the atmosphere can be deposited on a glacier by wet and dry deposition. Before the industrial revolution, these organic carbon species, then entirely of non-fossil origin, contain the contemporary atmospheric ${ }^{14} \mathrm{C}$ signal of the time when the snow deposited on the glacier (Jenk et al., 2006). For both WIOC and WSOC, carbon from biomass burning and oceanic organic matter can potentially introduce a reservoir effect (sources of aged carbon). The mixed age of trees in Swiss forests today is estimated to be slightly less than 40 years (Mohn et al., 2008). Back in time, prior to extensive human forest management, the mixed age of trees in Europe was likely older, and the mean age of old-growth-forest wood ranged from around 70 to 300 years depending on the region, i.e. the tree species present (Gavin, 2001; Zhang et al., 2017). Prior to the use of fossil fuels about $50 \%$ of WIOC is estimated to originate from biomass burning (Minguillon et al., 2011). For biogenic DOC, May et al. (2013) estimated a turnover time of around 3 to 5 years, corresponding to a $20 \%$ contribution from biomass burning. With a mean age of burned material (aged wood plus grass and bushes) of $150 \pm 100$ years, this results in a potential inbuilt age from biomass burning for WIOC and DOC of $75 \pm 50$ and $30 \pm 20$ years, respectively. Such an inbuilt age is negligible considering the analytical uncertainty, which is similarly the case for a bias from oceanic sources since concentrations of marine organic tracers are more than 1 order of magnitude lower than terrestrial tracers for the vast majority of glacier sites. This conclusion is supported by the fact that Uglietti et al. (2016) did not identify such a bias when comparing $\mathrm{WIO}^{14} \mathrm{C}$ ages with ages derived by independent methods.

For analysing $\mathrm{DO}^{14} \mathrm{C}$ in ice cores, one of the major limitations is the relatively low extraction efficiency, ranging from $64 \%$ (Steier et al., 2013) to $96 \%$ (May et al., 2013; Fang et al., 2019), and the high risk of sample contamination (Legrand et al., 2013) potentially introduced during drilling, storage and sample processing. A first attempt to use DOC for ${ }^{14} \mathrm{C}$ dating of ice samples was conducted by May (2009) using a set-up for a combined analysis of both the DOC and WIOC fraction with subsequent radiocarbon micro-analysis. However, these first results suggested a potential in situ production of ${ }^{14} \mathrm{C}$ in the DOC fraction based on the obtained super-modern $\mathrm{F}^{14} \mathrm{C}$ values (i.e. $\mathrm{F}^{14} \mathrm{C}$ values higher than ever observed in the recent or past ambient atmosphere). Building on these initial findings, May (2009) questioned the applicability of the DOC fraction for radiocarbon dating. Although the in situ ${ }^{14} \mathrm{C}$ production of ${ }^{14} \mathrm{CO}$ and ${ }^{14} \mathrm{CO}_{2}$ in air bubbles contained in polar ice has been studied thoroughly and is well understood (Van de Wal et al., 1994; Lal et al., 1997; Smith et al., 2000), possible mechanisms of ${ }^{14} \mathrm{C}$ in situ production followed by formation of organic compounds are not, and only few studies exist to date (Woon, 2002; Hoffmann, 2016). To further explore the potential of $\mathrm{DO}^{14} \mathrm{C}$ for dating ice, a DOC extraction set-up for radiocarbon analyses was designed and built at the Paul Scherrer Institut (PSI). In order to minimize potential contamination, the entire system is protected from ambient air by inert gas (helium) flow or vacuum. To maximize the oxidation efficiency, the PSI DOC 
methodology applies an ultraviolet (UV) photochemical oxidation step supported by addition of Fenton's reagent. The set-up has been characterized by a high extraction efficiency of $96 \%$ and a low overall process blank being superior in the resulting blank-to-sample ratio compared to other systems (Fang et al., 2019). The system can handle samples with volumes of up to $\sim 350 \mathrm{~mL}$. With this volume, samples with DOC concentrations as low as $25-30 \mu \mathrm{gg}^{-1}$ can be analysed, yielding the minimal carbon mass required for reliable ${ }^{14} \mathrm{C}$ analysis $(\sim 10 \mu \mathrm{g}$ ) . Pooling samples from several subsequent extractions would be feasible, allowing dating of samples with lower DOC concentration. In this study, we evaluate ${ }^{14} \mathrm{C}$ dating with the DOC fraction by comparing to results from the well-established and validated $\mathrm{WIO}^{14} \mathrm{C}$ dating method. This is not only analytically highly challenging but also challenging because of the very limited availability of the precious sampling material needed in a rather large quantity (total for both fractions $>500 \mathrm{~g}$ ), ideally covering a wide range of ages, from a few hundred to several thousands of years. Here, we succeeded in analysing such parallel samples from four different Eurasian glaciers.

\section{Sample preparation and ${ }^{14} \mathrm{C}$ analysis}

To validate the DOC ${ }^{14} \mathrm{C}$ dating technique, a total of 17 ice sections from the deep parts of ice cores from the four glaciers Colle Gnifetti, Belukha, Chongce (Core 1) and Shule Nanshan (SLNS) were selected (Fig. 1). They were sampled in parallel to directly compare DOC and WIOC concentrations and ${ }^{14} \mathrm{C}$ dating results. The high-alpine glacier Colle Gnifetti is located in the Monte Rosa massif of the Swiss Alps, close to the Italian border. A $76 \mathrm{~m}$ long core was retrieved from the glacier saddle in September 2015 at an altitude of 4450 ma.s.1. $\left(45^{\circ} 55^{\prime} 45.7^{\prime \prime} \mathrm{N}, 7^{\circ} 52^{\prime} 30.5^{\prime \prime} \mathrm{E}\right.$; Sigl et al., 2018), only $16 \mathrm{~m}$ away from the location of a previously dated core obtained in 2003 (Jenk et al., 2009). The low annual net accumulation rate at this site $\left(\sim 0.45 \mathrm{mw}\right.$.e. $\left.\mathrm{yr}^{-1}\right)$ provides access to old ice covering the Holocene (Jenk et al., 2009). Four samples were selected from the bottom $4 \mathrm{~m}$ closest to bedrock (72-76 m depth). The Belukha core was drilled in May/June 2018 from the saddle between the two summits of Belukha $\left(49^{\circ} 48^{\prime} 27.7^{\prime \prime} \mathrm{N}, 86^{\circ} 34^{\prime} 46.5^{\prime \prime} \mathrm{E}\right.$; 4055 ma.s.1.), the highest mountain in the Altai mountain range. The bedrock was reached, and the total length of the core is $160 \mathrm{~m}$. Three samples were analysed from the deepest part $(158-160 \mathrm{~m})$. Seven and three samples were analysed from the deep parts of SLNS and Chongce, respectively. The SLNS ice core was retrieved in May 2010 from the southern slope of the Shule Nanshan $\left(38^{\circ} 42^{\prime} 19.35^{\prime \prime} \mathrm{N}\right.$, $97^{\circ} 15^{\prime} 59.70^{\prime \prime} \mathrm{E}$; $5337 \mathrm{~m}$ a.s.1.). The bedrock was reached, and the total length of the ice core is $81.05 \mathrm{~m}$ (Hou et al., 2020). The Chongce ice cap is located in the western Kunlun Mountains on the north-western Tibetan Plateau, covering an area of $163.06 \mathrm{~km}^{2}$ with a volume of $38.16 \mathrm{~km}^{3}$

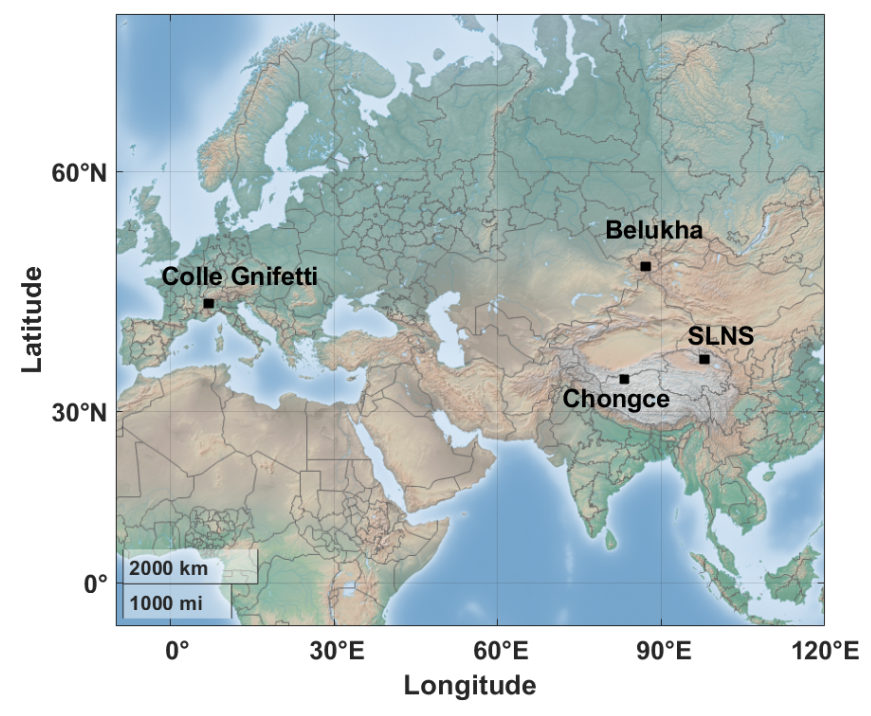

Figure 1. Location of the four glaciers Colle Gnifetti, Belukha, Chongce and Shule Nanshan (SLNS). Map made from MATLAB R2019b geobasemap. Colle Gnifetti is located in the Monte Rosa massif in the Swiss Alps; Belukha glacier in the Altai mountain range, Russia; the Chongce ice cap on the north-western Tibetan Plateau, China; and the SLNS at the southern slope of the Shule Nanshan, China.

(Hou et al., 2018). The ice analysed in this study was sampled from Chongce Core 1, one of three ice cores drilled in October $2012\left(35^{\circ} 14^{\prime} 5.77^{\prime \prime} \mathrm{N}, 81^{\circ} 7^{\prime} 15.34^{\prime \prime} \mathrm{E} ; 6010 \mathrm{ma.s.1}\right.$.). Two of those cores reached bedrock with lengths of $133.8 \mathrm{~m}$ (Core 1) and $135.8 \mathrm{~m}$ (Core 2). In 2013, two more ice cores were recovered from a higher altitude of $6100 \mathrm{~m}$ a.s.l., reaching bedrock with lengths of $216.6 \mathrm{~m}$ (Core 4) and $208.6 \mathrm{~m}$ (Core 5) (Hou et al., 2018). The annual net accumulation rate is about $0.14 \mathrm{mw}$.e. $\mathrm{yr}^{-1}$ for Core 3 , located less than $2 \mathrm{~km}$ away from Core 1. A summary of the metadata for the study sites and ice cores can be found in the Supplement (Table S1) and details about sampling depths and sample sizes in Tables 1 and 2. No results from any of the cores analysed in this study have been published previously.

All sampled ice sections were decontaminated in a cold room $\left(-20^{\circ} \mathrm{C}\right)$ by cutting off the surface layer $(\sim 3 \mathrm{~mm})$ and each section split into two parallel samples to perform both WIOC and DOC ${ }^{14} \mathrm{C}$ analysis. Samples for $\mathrm{WIO}^{14} \mathrm{C}$ dating were prepared following the protocol described in Uglietti et al. (2016), with a brief summary provided in the following. In order to remove potential contamination in the outer layer of the ice core, pre-cut samples from the inner part of the core were additionally rinsed with ultra-pure water (Sartorius, $18.2 \mathrm{M} \Omega \mathrm{cm}, \mathrm{TOC}<5 \mathrm{ppb}$ ), resulting in sample masses ranging from $\sim 300$ to $600 \mathrm{~g}$ (Table 1). To dissolve carbonate potentially present in the ice, melted samples were acidified with $\mathrm{HCl}$ to $\mathrm{pH}<2$ before being sonicated for $5 \mathrm{~min}$. Subsequently, the contained particles were filtered onto pre-baked (heated at $800^{\circ} \mathrm{C}$ for $5 \mathrm{~h}$ ) quartz fibre filters 
Table 1. WIOC samples analysed from Colle Gnifetti, Belukha, SLNS and Chongce ice cores.

\begin{tabular}{lrrrrrrr}
\hline Core section & $\begin{array}{r}\text { Depth } \\
(\mathrm{m})\end{array}$ & $\begin{array}{r}\text { Ice mass } \\
(\mathrm{kg})\end{array}$ & $\begin{array}{r}\text { WIOC } \\
(\mu \mathrm{g})\end{array}$ & $\begin{array}{r}\text { Concentration } \\
\left(\mu \mathrm{kg}^{-1}\right)\end{array}$ & $\begin{array}{r}\text { Bern AMS } \\
\text { no. }\end{array}$ & $\begin{array}{r}\mathrm{F}^{14} \mathrm{C} \\
( \pm 1 \sigma)\end{array}$ & $\begin{array}{r}14 \mathrm{C} \text { age } \\
(\mathrm{BP}, \pm 1 \sigma)\end{array}$ \\
\hline CG110 & $72.1-72.7$ & 0.570 & 35.2 & $61.9 \pm 3.3$ & 11770.1 .1 & $0.875 \pm 0.011$ & $1073 \pm 105$ \\
CG111 & $72.7-73.4$ & 0.539 & 38.7 & $71.8 \pm 3.8$ & 11771.1 .1 & $0.848 \pm 0.011$ & $1321 \pm 101$ \\
CG112 & $73.4-73.9$ & 0.536 & 23.7 & $44.1 \pm 2.4$ & 11772.1 .1 & $0.852 \pm 0.015$ & $1284 \pm 143$ \\
CG113 & $73.9-74.6$ & 0.549 & 39.8 & $72.4 \pm 3.8$ & 11773.1 .1 & $0.786 \pm 0.011$ & $1937 \pm 109$ \\
\hline Belukha412 & $158.3-159.0$ & 0.443 & 37.8 & $85.2 \pm 4.5$ & 11766.1 .1 & $0.367 \pm 0.010$ & $8055 \pm 211$ \\
Belukha414 & $159.5-160.3$ & 0.336 & 27.8 & $82.6 \pm 4.4$ & 11768.1 .1 & $0.212 \pm 0.014$ & $12473 \pm 535$ \\
Belukha415 & $160.3-160.9$ & 0.319 & 39.3 & $123.3 \pm 6.5$ & 11769.1 .1 & $0.100 \pm 0.011$ & $18462 \pm 899$ \\
\hline SLNS101 & $56.8-57.5$ & 0.420 & 41.5 & $98.9 \pm 2.1$ & 12325.1 .1 & $0.902 \pm 0.047$ & $825 \pm 420$ \\
SLNS113 & $64.7-65.4$ & 0.427 & 45.3 & $106.1 \pm 2.5$ & 12324.1 .1 & $0.852 \pm 0.046$ & $1284 \pm 438$ \\
SLNS122 & $68.9-69.7$ & 0.424 & 58.5 & $138.0 \pm 3.6$ & 12323.1 .1 & $0.807 \pm 0.046$ & $1727 \pm 459$ \\
SLNS127 & $71.8-72.5$ & 0.483 & 50.9 & $105.3 \pm 2.5$ & 12322.1 .1 & $0.695 \pm 0.046$ & $2921 \pm 532$ \\
SLNS136 & $76.7-77.5$ & 0.374 & 50.6 & $135.2 \pm 3.0$ & 12321.1 .1 & $0.521 \pm 0.046$ & $5235 \pm 706$ \\
SLNS139 & $78.9-79.6$ & 0.485 & 61.2 & $126.3 \pm 3.6$ & 12320.1 .1 & $0.521 \pm 0.045$ & $5232 \pm 703$ \\
SLNS141-142 & $80.3-81.0$ & 0.413 & 61.7 & $149.5 \pm 3.8$ & 12319.1 .1 & $0.489 \pm 0.046$ & $5754 \pm 750$ \\
\hline CC237 & $126.0-126.7$ & 0.352 & 22.4 & $63.7 \pm 1.8$ & 12328.1 .1 & $0.704 \pm 0.049$ & $2815 \pm 555$ \\
CC244 & $130.2-130.8$ & 0.311 & 29.8 & $95.9 \pm 2.2$ & 12327.1 .1 & $0.639 \pm 0.048$ & $3602 \pm 600$ \\
CC252 & $133.4-133.8$ & 0.174 & 23.8 & $136.7 \pm 4.3$ & 12326.1 .1 & $0.316 \pm 0.049$ & $9256 \pm 1250$ \\
\hline
\end{tabular}

Table 2. DOC samples analysed from Colle Gnifetti, Belukha, SLNS and Chongce ice cores.

\begin{tabular}{|c|c|c|c|c|c|c|c|c|}
\hline Core section & $\begin{array}{r}\text { Depth } \\
(\mathrm{m})\end{array}$ & $\begin{array}{r}\text { Ice mass } \\
(\mathrm{kg})\end{array}$ & $\begin{array}{r}\text { DOC } \\
(\mu \mathrm{g})\end{array}$ & $\begin{array}{r}\text { Concentration } \\
\qquad\left(\mu \mathrm{gkg}^{-1}\right)\end{array}$ & $\begin{array}{r}\text { Bern AMS } \\
\text { no. }\end{array}$ & $\begin{array}{r}\mathrm{F}^{14} \mathrm{C} \\
( \pm 1 \sigma)\end{array}$ & $\begin{array}{r}{ }^{14} \mathrm{C} \text { age } \\
(\mathrm{BP}, \pm 1 \sigma)\end{array}$ & $\begin{array}{l}\text { DOC / } \\
\text { WIOC }\end{array}$ \\
\hline CG110 & $72.1-72.7$ & 0.171 & 18.9 & $110.0 \pm 2.7$ & 11575.1 .1 & $0.943 \pm 0.030$ & $474 \pm 259$ & 1.8 \\
\hline CG111 & $72.7-73.4$ & 0.207 & 25.5 & $122.9 \pm 3.0$ & 11576.1 .1 & $0.901 \pm 0.021$ & $836 \pm 190$ & 1.7 \\
\hline CG112 & $73.4-73.9$ & 0.248 & 23.6 & $95.0 \pm 2.3$ & 11577.1 .1 & $0.889 \pm 0.021$ & $943 \pm 192$ & 2.2 \\
\hline CG113 & $73.9-74.6$ & 0.246 & 29.5 & $119.4 \pm 2.9$ & 11578.1 .1 & $0.849 \pm 0.016$ & $1312 \pm 151$ & 1.7 \\
\hline Belukha412 & $158.3-159.0$ & 0.172 & 28.5 & $165.0 \pm 4.0$ & 11581.1 .1 & $0.315 \pm 0.024$ & $9284 \pm 624$ & 1.9 \\
\hline Belukha414 & $159.5-160.3$ & 0.128 & 41.9 & $327.4 \pm 7.9$ & 11584.1 .1 & $0.239 \pm 0.019$ & $11505 \pm 648$ & 4.0 \\
\hline Belukha415 & $160.3-160.9$ & 0.102 & 23.7 & $231.0 \pm 5.6$ & 11585.1 .1 & $0.144 \pm 0.041$ & $15584 \pm 2365$ & 1.9 \\
\hline SLNS101 & $56.8-57.5$ & 0.238 & 44.0 & $184.9 \pm 4.5$ & 12458.1 .1 & $0.972 \pm 0.016$ & $227 \pm 131$ & 1.9 \\
\hline SLNS113 & $64.7-65.4$ & 0.213 & 39.4 & $185.2 \pm 4.5$ & 12459.1 .1 & $0.942 \pm 0.016$ & $484 \pm 137$ & 1.7 \\
\hline SLNS122 & $68.9-69.7$ & 0.234 & 57.9 & $248.0 \pm 6.0$ & 12460.1 .1 & $0.773 \pm 0.010$ & $2073 \pm 101$ & 1.8 \\
\hline SLNS127 & $71.8-72.5$ & 0.252 & 57.8 & $229.7 \pm 5.5$ & 12461.1 .1 & $0.730 \pm 0.009$ & $2527 \pm 101$ & 2.2 \\
\hline SLNS136 & $76.7-77.5$ & 0.220 & 48.3 & $219.1 \pm 5.3$ & 12462.1 .1 & $0.657 \pm 0.009$ & $3380 \pm 112$ & 1.6 \\
\hline SLNS139 & $78.9-79.6$ & 0.208 & 48.1 & $230.8 \pm 5.6$ & 12463.1 .1 & $0.580 \pm 0.009$ & $4381 \pm 131$ & 1.8 \\
\hline SLNS141-142 & $80.3-81.0$ & 0.246 & 43.8 & $177.5 \pm 4.3$ & 12464.1 .1 & $0.550 \pm 0.010$ & $4809 \pm 151$ & 1.2 \\
\hline CC237 & $126.0-126.7$ & 0.208 & 28.5 & $136.6 \pm 3.3$ & 12454.1 .1 & $0.980 \pm 0.023$ & $161 \pm 185$ & 2.1 \\
\hline CC244 & $130.2-130.8$ & 0.167 & 21.7 & $129.8 \pm 3.1$ & 12455.1 .1 & $0.800 \pm 0.018$ & $1789 \pm 185$ & 1.4 \\
\hline $\mathrm{CC} 252$ & $133.4-133.8$ & 0.120 & 24.3 & $202.5 \pm 4.9$ & 12456.1 .1 & $0.546 \pm 0.016$ & $4854 \pm 239$ & 1.5 \\
\hline
\end{tabular}

(Pallflex Tissueqtz-2500QAT-UP). In a second carbonate removal step, the filters were acidified three times with a total amount of $50 \mu \mathrm{L} 0.2 \mathrm{M} \mathrm{HCl}$, left for $1 \mathrm{~h}$, rinsed with $5 \mathrm{~mL}$ ultra-pure water and finally left again for drying. These initial steps were performed in a laminar-flow box to ensure clean conditions. At the Laboratory for the Analysis of Radiocarbon with AMS (LARA) of the University of Bern, the parti- cle samples were then combusted in a thermo-optical OC-EC (organic carbon and elemental carbon) analyser (Model4L, Sunset Laboratory Inc, USA) equipped with a non-dispersive infrared (NDIR) cell to quantify the $\mathrm{CO}_{2}$ produced using the well-established Swiss 4S protocol for OC-EC separation (Zhang et al., 2012). Being coupled to a $200 \mathrm{kV}$ compact accelerator mass spectrometer (AMS; MIni CArbon DAting 
System, MICADAS) equipped with a gas ion source via a Gas Interface System (GIS; Ruff et al., 2007; Synal et al., 2007; Szidat et al., 2014), the LARA Sunset-GIS-AMS system (Agrios et al., 2015; Agrios et al., 2017) allowed for final, direct online ${ }^{14} \mathrm{C}$ measurements of the $\mathrm{CO}_{2}$ produced from the WIOC fraction.

For $\mathrm{DO}^{14} \mathrm{C}$ analysis, sample preparation follows the procedure described in Fang et al. (2019). After transfer of precut samples to the laboratory and before being melted, samples were further decontaminated in the pre-cleaned melting vessel of the extraction set-up by rinsing with ultra-pure water (sample mass loss of about 20\%-30\%), all performed under a helium atmosphere. Simultaneously, a pre-cleaning step was applied to remove potential contamination in the system. For this, $50 \mathrm{~mL}$ ultra-pure water was injected into the reactor and acidified with $1 \mathrm{~mL}$ of $85 \% \mathrm{H}_{3} \mathrm{PO}_{4}$. To enhance the oxidation efficiency, $2 \mathrm{~mL}$ of $100 \mathrm{ppm} \mathrm{FeSO}_{4}$ and $1 \mathrm{~mL}$ of $50 \mathrm{mM} \mathrm{H} \mathrm{O}_{2}$ (Fenton's reagent) were also injected into the base water before turning on the UV lights for $\sim 20 \mathrm{~min}$, thereby monitoring the process via the online NDIR $\mathrm{CO}_{2}$ analyser. After the ice melted, the meltwater was filtrated under a helium atmosphere using a pre-baked in-line quartz fibre filter. The sample volume was determined by measuring the reactor fill level. The filtrate was acidified by mixing with the pre-treated base water. After degassing of $\mathrm{CO}_{2}$ from inorganic carbon was completed, as monitored by the $\mathrm{CO}_{2}$ detector, $1 \mathrm{~mL}$ of $50 \mathrm{mM} \mathrm{H} \mathrm{O}_{2}$ was injected into the reactor right before the irradiation started. During UV oxidation, water vapour was removed by cryogenic trapping at $-60^{\circ} \mathrm{C}$, and produced $\mathrm{CO}_{2}$ was trapped in liquid nitrogen. All steps were carried out under a constant flow of helium. The sample $\mathrm{CO}_{2}$ was further cleaned from residual water vapour and quantified manometrically before being sealed into a glass vial for offline ${ }^{14} \mathrm{C}$ analyses. The $\mathrm{CO}_{2}$ gas from DOC in the glass vial was directly injected into the MICADAS using a cracking system for glass vials under vacuum, allowing the $\mathrm{CO}_{2}$ gas to then be carried in a helium flow to the AMS ion source (Wacker et al., 2013). Procedural blanks were determined and continuously monitored by processing and analysing frozen ultra-pure water (Sartorius, $18.2 \mathrm{M} \Omega \mathrm{cm}$, TOC $<5 \mathrm{ppb}$ ) similar to natural ice samples. They were prepared every time when cutting ice and then processed and analysed along with the samples at least twice a week. Procedural blanks are $1.3 \pm 0.6 \mu \mathrm{g} C$ with an $\mathrm{F}^{14} \mathrm{C}$ of $0.69 \pm 0.15$ $(n=76)$ and $1.9 \pm 1.6 \mu \mathrm{g} \mathrm{C}$ with an $\mathrm{F}^{14} \mathrm{C}$ value of $0.68 \pm 0.13$ $(n=30)$ for WIOC and DOC, respectively.

All ${ }^{14} \mathrm{C}$ results are expressed as fraction modern $\left(\mathrm{F}^{14} \mathrm{C}\right)$, which is the ${ }^{14} \mathrm{C} /{ }^{12} \mathrm{C}$ ratio of the sample divided by the same ratio of the modern standard referenced to the year 1950 (NIST, SRM 4990C, oxalic acid II), both being normalized to $-25 \%$ in $\delta^{13} \mathrm{C}$ to account for isotopic fractionation. All AMS $\mathrm{F}^{14} \mathrm{C}$ values presented here are finally corrected for the system and method characteristic contributions as reported previously (e.g. Uglietti et al., 2016 and Fang et al., 2019). For WIOC analysis using the Sunset-GIS-AMS sys- tem this includes a correction for the system background, i.e. constant contamination $\left(0.91 \pm 0.18 \mu \mathrm{gC}\right.$ with $\mathrm{F}^{14} \mathrm{C}$ of $0.72 \pm 0.11)$. For the cracking system applied for DOC samples the constant contamination is $0.06 \pm 0.18 \mu \mathrm{g} \mathrm{C}$ with $\mathrm{F}^{14} \mathrm{C}$ of $0.50 \pm 0.11$. Further corrections applied account for the AMS cross-contamination $(0.2 \%$ of the previous sample) and procedural blanks (see above). All uncertainties were propagated throughout data processing until final ${ }^{14} \mathrm{C}$ calibration. These corrections have a larger effect on low-carbonmass samples (higher noise-to-sample ratio), resulting in a larger dating uncertainty. Therefore, we only discuss samples with a carbon mass larger than $10 \mu \mathrm{g}$ as recommended in Uglietti et al. (2016). Radiocarbon ages are calculated following the law of radioactive decay using 5570 years as the half-life of radiocarbon; thus age equals $-8033 \times \ln \left(\mathrm{F}^{14} \mathrm{C}\right)$, with -8033 years being Libby's mean lifetime of radiocarbon. Radiocarbon ages are given in years before present (BP), with the year of reference being 1950 (Stuiver and Polach, 1977). To obtain calibrated ${ }^{14} \mathrm{C}$ ages, the online program OxCal v4.3.2 with the IntCal13 radiocarbon calibration curve was used (Reimer et al., 2013; Ramsey, 2017). Calibrated ages, also given in years before present, are indicated with cal BP and denote the $1 \sigma$ range unless stated otherwise.

\section{Results}

\subsection{DOC and WIOC concentrations}

DOC concentrations are generally higher compared to the corresponding WIOC concentrations (Fig. 2). For all samples from the four glaciers, the DOC / WIOC concentration ratio ranges from 1.2 to 4.0 , with an average of $1.9 \pm 0.6$ (Table 2). This is at the lower end of previously reported average DOC / WIOC ratios of 2-8 (Legrand et al., 2007, 2013; Fang et al., 2021). This is likely explained by temporal variability because most samples in this study are several thousand years old, whereas the literature data only cover the last few centuries, including values from the industrial period, in which additional anthropogenic sources exist (e.g. fossil DOC precursors). It is interesting to note that the average DOC/WIOC ratio at Belukha (2.5) is higher compared to the other sites (at Colle Gnifetti, SLNS and Chongce it is $1.8,1.7$ and 1.6, respectively). Because the Belukha glacier is surround by extensive Siberian forests, the higher ratio may be explained by particularly high emissions of biogenic volatile organic compounds. This is corroborated by the observation that DOC concentrations are highest at this site $\left(241 \pm 82 \mu \mathrm{g} \mathrm{kg}^{-1}\right)$ (Fig. 2). Absolute concentrations of DOC and WIOC are slightly lower at Colle Gnifetti ( $112 \pm 12$ and $63 \pm 13 \mu \mathrm{g} \mathrm{kg}^{-1}$, respectively) compared to the other three glaciers (Tables 1 and 2). Mean DOC and WIOC concentrations in the ice from the Tibetan Plateau are $211 \pm 28$ and $123 \pm 19 \mu \mathrm{g} \mathrm{kg}^{-1}$ for SLNS and $156 \pm 40$ and $99 \pm 37 \mu \mathrm{g} \mathrm{kg}^{-1}$ for Chongce, respectively. The values mea- 


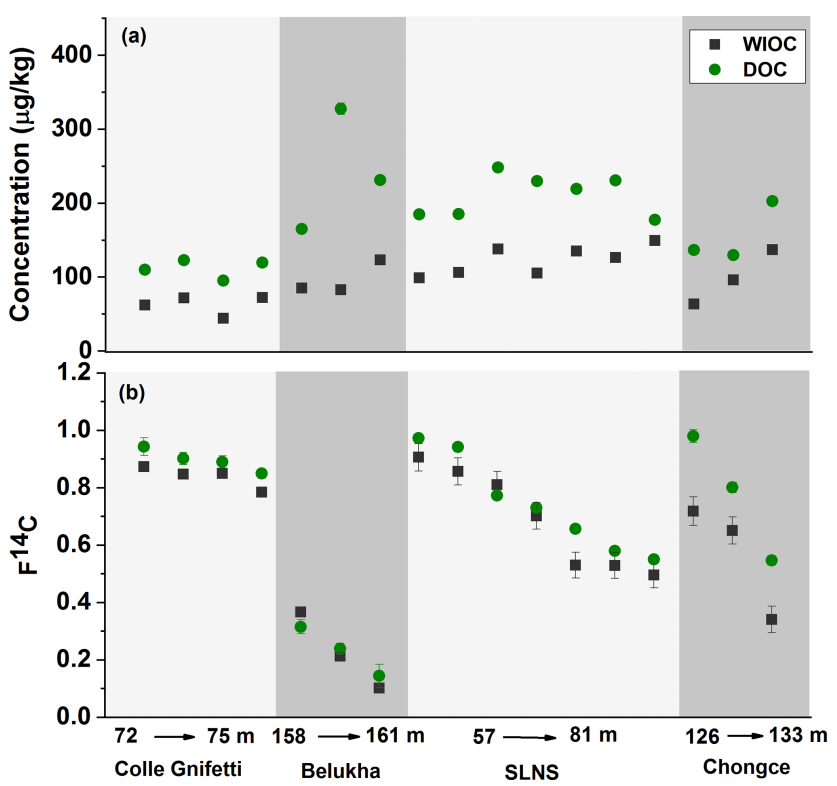

Figure 2. Comparison of results from the WIOC and DOC fractions for the four studied sites. (a) Concentrations, (b) $\mathrm{F}^{14} \mathrm{C}$. The error bars denote the overall analytical $1 \sigma$ uncertainty.

sured for the samples from the Tibetan Plateau are higher compared to the pre-industrial (PI) average values found in European Alpine glaciers, not only compared to the few samples from Colle Gnifetti of this study, but also compared to previously reported values from the Fiescherhorn glacier, with PI DOC of $\sim 95 \mu \mathrm{g} \mathrm{kg}^{-1}$ (Fang et al., 2021) and PI

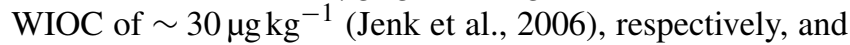
from Colle Gnifetti with PI WIOC of $\sim 30 \mu \mathrm{g} \mathrm{kg}^{-1}$ (Legrand et al., 2007; Jenk et al., 2006).

\subsection{Radiocarbon results}

For all four sites, $\mathrm{F}^{14} \mathrm{C}$ of both fractions (WIOC and DOC) decreases with depth, indicating the expected increase in age (Fig. 2, Tables 1 and 2). For three of the sites (Colle Gnifetti, Belukha and SLNS), the corresponding DOC and WIOC fractions yielded comparable $\mathrm{F}^{14} \mathrm{C}$ values with no statistical evidence for a significant difference (Mann-Whitney $U$ test, $U=79.5, n=14, p=0.41>0.05$ ). They scatter along the $1: 1$ ratio line and are significantly correlated (Pearson correlation coefficient $r=0.986, p<0.01, n=14)$, and both intercept $(0.025 \pm 0.034)$ and slope $(1.034 \pm 0.050)$ are not significantly different from 0 and 1 , respectively (Fig. 3). Nevertheless, a slight systematic offset towards lower $\mathrm{F}^{14} \mathrm{C}$ values for WIOC compared to DOC seems evident if looking at Figs. 2 and 3. This is particularly obvious for the samples from Chongce, characterized by high mineral dust load and from a site of very high elevation with low net accumulation. For these samples, the $\mathrm{F}^{14} \mathrm{C}$ DOC-WIOC offset is significant (discussion in Sect. 4.2 and 4.3).
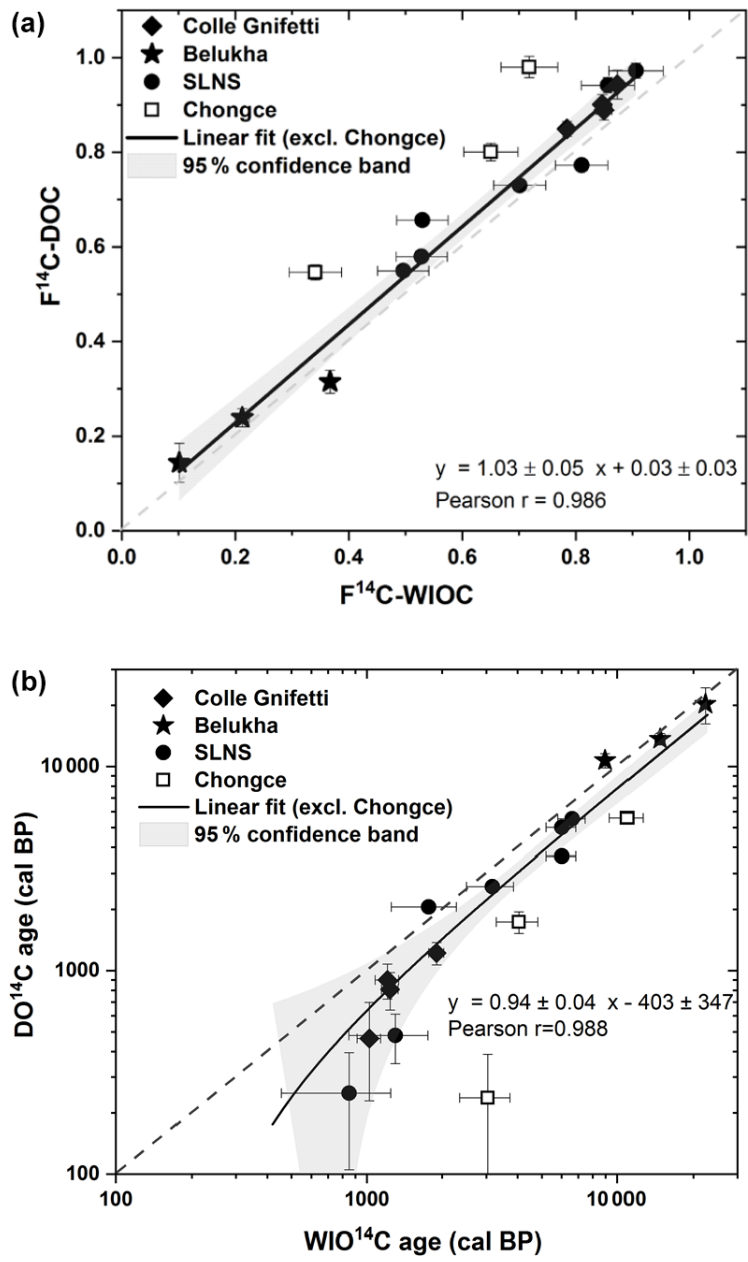

Figure 3. Scatter plot showing the correlation between $\mathrm{WIO}^{14} \mathrm{C}$ and $\mathrm{DO}^{14} \mathrm{C}$ results for the four sites (see legend). In terms of $\mathrm{F}^{14} \mathrm{C}$ (a) and calibrated ages (b). For the linear fit in both panels, the data from Chongce (open symbols) were excluded. Shaded areas indicate the $95 \%$ confidence band.

For all sites, the calibrated ${ }^{14} \mathrm{C}$ ages from both fractions show an increase in age with depth (Table 3 ). The ages range from $\sim 0.2$ to 20.3 cal kyr BP for DOC and $\sim 0.8$ to 22.4 cal kyr BP for WIOC, respectively. In both fractions, the oldest age was derived for the sample from the deepest part of the Belukha ice core. Samples from Colle Gnifetti generally showed younger ages $(<2$ cal kyr BP). The two ice cores from the Tibetan Plateau (SLNS and Chongce) cover a similar age span, from $\sim 0.2 \pm 0.1$ to $5.5 \pm 0.3 \mathrm{cal} \mathrm{kyr} \mathrm{BP}$ in the DOC fraction. WIO ${ }^{14} \mathrm{C}$ resulted in a similar age range for the samples from SLNS $(0.8 \pm 0.4$ to $6.6 \pm 0.8 \mathrm{cal} \mathrm{kyr} \mathrm{BP})$ but was considerably older for Chongce ( $3.1 \pm 0.7$ to $11.0 \pm$ 1.7 cal kyr BP; discussion in Sect. 4.2 and 4.3). 
Table 3. Calibrated $\mathrm{WIO}^{14} \mathrm{C}$ and $\mathrm{DO}^{14} \mathrm{C}$ ages using $\mathrm{OxCal}$ v4.3.2 with the Intcal13 radiocarbon calibration curve. Ages are given as the OxCal-provided $\mu$ age $\pm 1 \sigma$, which is the calibrated mean age accounting for the age probability distribution. In addition, calibrated ages derived when applying the OxCal sequence deposition model for further constraint are shown.

\begin{tabular}{lrrrr}
\hline Core section & $\begin{array}{r}\text { WIOC } \\
\text { calibrated age } \\
(\text { cal BP })\end{array}$ & $\begin{array}{r}\text { WIOC calibrated age } \\
\text { with sequence } \\
\text { (cal BP) }\end{array}$ & $\begin{array}{r}\text { DOC } \\
\text { calibrated age } \\
(\text { cal BP })\end{array}$ & $\begin{array}{r}\text { DOC calibrated age } \\
\text { with sequence } \\
\text { (cal BP) }\end{array}$ \\
\hline CG110 & $1004 \pm 119$ & $968 \pm 104$ & $464 \pm 235$ & $403 \pm 196$ \\
CG111 & $1224 \pm 103$ & $1174 \pm 86$ & $810 \pm 169$ & $749 \pm 123$ \\
CG112 & $1190 \pm 142$ & $1292 \pm 103$ & $901 \pm 176$ & $947 \pm 139$ \\
CG113 & $1889 \pm 138$ & $1869 \pm 143$ & $1222 \pm 153$ & $1248 \pm 144$ \\
\hline Belukha412 & $8960 \pm 266$ & $8954 \pm 268$ & $10695 \pm 867$ & $10686 \pm 865$ \\
Belukha414 & $14796 \pm 782$ & $14802 \pm 774$ & $13646 \pm 893$ & $13670 \pm 880$ \\
Belukha415 & $22441 \pm 1107$ & $22497 \pm 1107$ & $20264 \pm 4073$ & $20393 \pm 4033$ \\
\hline SLNS101 & $848 \pm 396$ & $701 \pm 315$ & $250 \pm 145$ & $226 \pm 137$ \\
SLNS113 & $1297 \pm 453$ & $1255 \pm 331$ & $480 \pm 131$ & $505 \pm 111$ \\
SLNS122 & $1769 \pm 514$ & $1901 \pm 430$ & $2057 \pm 129$ & $2056 \pm 129$ \\
SLNS127 & $3175 \pm 679$ & $3221 \pm 629$ & $2585 \pm 125$ & $2585 \pm 125$ \\
SLNS136 & $6030 \pm 824$ & $5426 \pm 620$ & $3635 \pm 138$ & $3636 \pm 137$ \\
SLNS139 & $6026 \pm 820$ & $6177 \pm 567$ & $5014 \pm 191$ & $5007 \pm 187$ \\
SLNS141-142 & $6626 \pm 831$ & $7081 \pm 689$ & $5519 \pm 188$ & $5531 \pm 176$ \\
\hline CC237 & $3051 \pm 703$ & $2886 \pm 617$ & $237 \pm 151$ & $233 \pm 153$ \\
CC244 & $4057 \pm 769$ & $4210 \pm 713$ & $1737 \pm 211$ & $1738 \pm 212$ \\
CC252 & $11000 \pm 1697$ & $11017 \pm 1716$ & $5580 \pm 294$ & $5580 \pm 295$ \\
\hline
\end{tabular}

\section{Discussion}

\subsection{Radiocarbon dating with the DOC fraction}

In Table 3, we present the first radiocarbon dating results of ice using the DOC fraction. The DOC calibrated ${ }^{14} \mathrm{C}$ age of ice increases with depth for all four sites, as expected for undisturbed glacier archives from the accumulation zone. For samples from three out of the four sites, our results (Sect. 3) indicate no significant difference in $\mathrm{F}^{14} \mathrm{C}$ between $\mathrm{DOC}$ and WIOC, with the latter fraction being validated for allowing accurate dating of the surrounding ice (Uglietti et al., 2016). With the new $\mathrm{DO}^{14} \mathrm{C}$ dating method, an average dating uncertainty of around \pm 200 years was achieved for samples with an absolute carbon mass of 20-60 $\mu \mathrm{g}$ and ice younger than $\sim 6 \mathrm{kyr}$ (Tables 2 and 3). The analytical uncertainty mainly arises from correction for the procedure blank introduced during sample treatment prior to AMS analysis (see Sect. 2 for details about other corrections), contributing $20 \%$ to $70 \%$ of the final overall dating uncertainty. The contribution thereby depends on carbon mass (larger for small samples) and sample age (larger the bigger the difference between sample and blank $\mathrm{F}^{14} \mathrm{C}$ ). How the overall analytical uncertainty in $\mathrm{F}^{14} \mathrm{C}$ decreases with higher carbon mass is shown in Fig. S1 in the Supplement. For DOC concentrations observed in this study, an initial ice mass of about $250 \mathrm{~g}$ was required, with about $20 \%-30 \%$ of the ice being removed during the decontamination processes inside the DOC set-up, yielding $\sim 200 \mathrm{~g}$ of ice available for final analysis. Expected based on previously reported DOC / WIOC concentration ratios (Sect. 3.1), the results here confirmed that with this new technique, the required ice mass can be reduced by more than a factor of 2 compared to the mass needed for ${ }^{14} \mathrm{C}$ dating using the WIOC fraction. Consequently, using the DOC instead of the WIOC fraction for ${ }^{14} \mathrm{C}$ dating, a higher dating precision can be achieved for ice samples of similar mass. An additional benefit is that the DOC extraction procedure allows the removal of inorganic carbon to be monitored for completeness (see Sect. 2), which is important to avoid a potential age bias (see Sect. 4.3).

\subsection{Potential contribution of ${ }^{14} \mathrm{C}$ in situ production to DO $^{14} \mathrm{C}$}

Previous studies have suggested that ${ }^{14} \mathrm{C}$ of the DOC fraction may be influenced by in situ production of ${ }^{14} \mathrm{C}$ in the ice matrix (May 2009; Hoffman 2016). Induced by cosmic radiation, the production of ${ }^{14} \mathrm{C}$ atoms within the ice matrix, i.e. by spallation of oxygen within the water molecule, is a well-known process (Lal et al., 1987; Van de Wal et al., 1994). Earlier studies have indicated that in-situ-produced ${ }^{14} \mathrm{C}$ atoms mostly form $\mathrm{CO}, \mathrm{CO}_{2}$ and $\mathrm{CH}_{4}$ (Petrenko et al., 2013) but also can form methanol and formic acid (Yankwich et al., 1946; Woon, 2002). The mechanism of incorporation of in-situ-produced ${ }^{14} \mathrm{C}$ incorporation into organic molecules is not well understood (Woon, 2002; Hoffman, 2016). Hoff- 
Table 4. Estimate of the effect from in situ ${ }^{14} \mathrm{C}$ production on $\mathrm{F}^{14} \mathrm{C}$-DOC. For comparison, the measured $\mathrm{F}^{14} \mathrm{C}$ offset between $\mathrm{DOC}$ and WIOC is also shown.

\begin{tabular}{|c|c|c|c|c|c|c|c|c|c|}
\hline Core section & $\begin{array}{r}\text { Ice } \\
\text { mass } \\
(\mathrm{g})\end{array}$ & $\begin{array}{r}\text { Carbon } \\
\text { mass } \\
(\mu \mathrm{g})\end{array}$ & $\begin{array}{r}\text { Depth } \\
\text { (mw.e.) }\end{array}$ & $\begin{array}{r}\mathrm{P}_{\mathrm{O}} \\
\left({ }^{14} \mathrm{C} \text { atoms }\right. \\
\mathrm{g}^{-1}{\left.\text { ice } y r^{-1}\right)}^{-1}\end{array}$ & $\begin{array}{r}\text { In situ } \\
{ }^{14} \mathrm{C} \\
\text { (atoms) }\end{array}$ & $\begin{array}{r}\text { In situ } \\
\mathrm{F}^{14} \mathrm{C}-\mathrm{DOC} \\
\text { offset }\end{array}$ & $\begin{array}{r}\text { Observed } \mathrm{F}^{14} \mathrm{C} \\
\text { DOC-WIOC } \\
\text { offset }\end{array}$ & $\begin{array}{r}\text { In-situ- } \\
\text { corrected } \\
\mathrm{F}^{14} \mathrm{C}-\mathrm{DOC}\end{array}$ & $\begin{array}{r}\text { In-situ-corrected } \\
\text { DOC calibrated } \\
\text { age (cal BP) }\end{array}$ \\
\hline CG110 & 171 & 18.9 & 55.8 & 328 & 1197 & $0.033 \pm 0.013$ & $0.068 \pm 0.032$ & $0.910 \pm 0.033$ & $752 \pm 273$ \\
\hline CG111 & 207 & 25.5 & 56.3 & 328 & 1197 & $0.030 \pm 0.012$ & $0.053 \pm 0.024$ & $0.901 \pm 0.024$ & $1045 \pm 207$ \\
\hline CG112 & 248 & 23.6 & 56.7 & 328 & 1197 & $0.038 \pm 0.015$ & $0.037 \pm 0.026$ & $0.889 \pm 0.026$ & $1225 \pm 250$ \\
\hline CG113 & 246 & 29.5 & 57.0 & 328 & 1197 & $0.030 \pm 0.012$ & $0.064 \pm 0.019$ & $0.849 \pm 0.020$ & $1546 \pm 208$ \\
\hline Belukha412 & 172 & 28.5 & 142.7 & 286 & 921 & $0.017 \pm 0.007$ & $-0.052 \pm 0.026$ & $0.315 \pm 0.025$ & $11271 \pm 902$ \\
\hline Belukha414 & 128 & 41.9 & 143.9 & 286 & 921 & $0.009 \pm 0.003$ & $0.027 \pm 0.024$ & $0.239 \pm 0.020$ & $14096 \pm 964$ \\
\hline Belukha415 & 102 & 23.7 & 144.5 & 286 & 921 & $0.012 \pm 0.005$ & $0.043 \pm 0.043$ & $0.144 \pm 0.041$ & $21571 \pm 4753$ \\
\hline SLNS101 & 238 & 44 & 47.9 & 345 & 2666 & $0.044 \pm 0.017$ & $0.070 \pm 0.050$ & $0.972 \pm 0.023$ & $587 \pm 187$ \\
\hline SLNS113 & 213 & 39.4 & 54.4 & 345 & 2656 & $0.044 \pm 0.017$ & $0.089 \pm 0.050$ & $0.942 \pm 0.023$ & $837 \pm 184$ \\
\hline SLNS122 & 234 & 57.9 & 58.1 & 345 & 2651 & $0.033 \pm 0.013$ & $-0.034 \pm 0.047$ & $0.773 \pm 0.016$ & $2483 \pm 210$ \\
\hline SLNS127 & 183 & 57.8 & 60.5 & 345 & 2647 & $0.026 \pm 0.010$ & $0.029 \pm 0.047$ & $0.730 \pm 0.014$ & $2967 \pm 197$ \\
\hline SLNS136 & 220 & 48.3 & 64.7 & 345 & 2641 & $0.037 \pm 0.014$ & $0.135 \pm 0.047$ & $0.657 \pm 0.017$ & $4264 \pm 304$ \\
\hline SLNS139 & 208 & 48.1 & 66.5 & 345 & 2638 & $0.035 \pm 0.014$ & $0.058 \pm 0.046$ & $0.580 \pm 0.016$ & $5600 \pm 290$ \\
\hline SLNS141-142 & 246 & 43.8 & 67.7 & 345 & 2636 & $0.045 \pm 0.018$ & $0.061 \pm 0.047$ & $0.550 \pm 0.020$ & $6323 \pm 363$ \\
\hline CC237 & 208 & 28.5 & 113.7 & 497 & 5371 & $0.120 \pm 0.046$ & $0.275 \pm 0.054$ & $0.980 \pm 0.052$ & $1240 \pm 498$ \\
\hline CC244 & 167 & 21.7 & 117.6 & 497 & 5353 & $0.126 \pm 0.049$ & $0.161 \pm 0.051$ & $0.800 \pm 0.052$ & $3509 \pm 799$ \\
\hline $\mathrm{CC} 252$ & 120 & 24.3 & 120.2 & 497 & 5341 & $0.080 \pm 0.031$ & $0.231 \pm 0.051$ & $0.546 \pm 0.035$ & $7007 \pm 635$ \\
\hline
\end{tabular}

mann (2016) performed neutron irradiation experiments on Alpine glacier ice, showing that about $11 \%-25 \%$ of the initially produced ${ }^{14} \mathrm{C}$ atoms entered into the DOC fraction. The resulting effect on $\mathrm{F}^{14} \mathrm{C}$ of DOC consequently depends on (i) the number of ${ }^{14} \mathrm{C}$ atoms produced in the ice $\left({ }^{14} \mathrm{C}\right.$ in situ production); (ii) the fraction of these atoms incorporated into DOC; and because $\mathrm{F}^{14} \mathrm{C}$ is based on a ${ }^{14} \mathrm{C} /{ }^{12} \mathrm{C}$ ratio, (iii) the DOC concentration in the ice (the higher the concentration the smaller the resulting shift in $\mathrm{F}^{14} \mathrm{C}$-DOC).

The natural neutron flux, relevant for the ${ }^{14} \mathrm{C}$ production rate, strongly depends on altitude and latitude with a generally uniform energy distribution of the incoming neutrons (Gordon et al., 2004). The ${ }^{14} \mathrm{C}$ in situ production in natural ice further depends on the depth in the glacier and the snow accumulation rate of the site (Lal et al., 1987), determining the total received neutron radiation. Following Lal et al. (1987), the number of in-situ-produced ${ }^{14} \mathrm{C}$ atoms in each of our ice samples was estimated assuming an average incorporation into DOC of $18 \pm 7 \%$ (Hoffmann, 2016) (Table 4, equations and input parameters in the Supplement). The average $\mathrm{F}^{14} \mathrm{C}$-DOC shift for all samples is $0.044 \pm 0.033$. We find a good correlation between the measured $\mathrm{F}^{14} \mathrm{C}$ DOC-WIOC offset and the ${ }^{14} \mathrm{C}$ in-situ-caused $\mathrm{F}^{14} \mathrm{C}$-DOC shift, which explains about $50 \%$ of the offset (Pearson $r=$ 0.82; Fig. 4), and after correcting for, it improves the overall agreement between $\mathrm{F}^{14} \mathrm{C}$ of DOC and WIOC (Fig. 5). The shift is largest for the Chongce samples $(0.109 \pm 0.048)$ as a result of the high production rate at $6 \mathrm{~km}$ altitude in combination with the low annual net accumulation rate at this site $\left(0.14 \mathrm{~m}\right.$ w.e. $\left.\mathrm{yr}^{-1}\right)$. The calculated shift for samples from the SLNS core, at a similar latitude but from a site lower in altitude $(5 \mathrm{~km})$ and experiencing higher net accumulation $\left(0.21 \mathrm{mw}\right.$ we. $\left.\mathrm{yr}^{-1}\right)$, is significantly lower, with $0.038 \pm 0.016$. The samples from Belukha and Colle Gnifetti are least affected $(0.013 \pm 0.006$ and $0.033 \pm 0.013$, respectively).

We find that while the effect of in situ ${ }^{14} \mathrm{C}$ production causes only a negligible shift in $\mathrm{F}^{14} \mathrm{C}$-DOC for most samples (masked by the analytical uncertainty), it can become significant for ice samples from sites of exceptionally high altitude and experiencing low annual net accumulation rates in addition, such as the Chongce ice cap (6010 ma.s.l., $0.14 \mathrm{mw}$ w.e. $\mathrm{yr}^{-1}$; Fig. 4). Note that for any site, the size of this effect is reduced with higher DOC concentration of the sample.

\subsection{Potential contribution of carbonates to ${ }^{14} \mathrm{C}$ of WIOC}

Under the basic assumption that the initially emitted fractions of DOC and WIOC are of similar age, an additional contribution from ${ }^{14} \mathrm{C}$-depleted carbonate (low $\mathrm{F}^{14} \mathrm{C}$ ) to the WIOC would cause an $\mathrm{F}^{14} \mathrm{C}$ offset between the two fractions. Previously published WIOC ${ }^{14} \mathrm{C}$ ages from the upper parts of the Chongce Core 2 and Core 4, less than 2 and $\sim 6 \mathrm{~km}$ away from Core 1 , did show large scatter with no clear increase in age with depth for samples younger than $2 \mathrm{kyr}$. It was speculated that this was at least partly caused by the visible, exceptionally high loading of mineral dust on the WIOC filters (Hou et al., 2018). Such high mineral dust loading was also observed during filtration of the Chongce Core 1 samples presented here. High mineral dust content in 


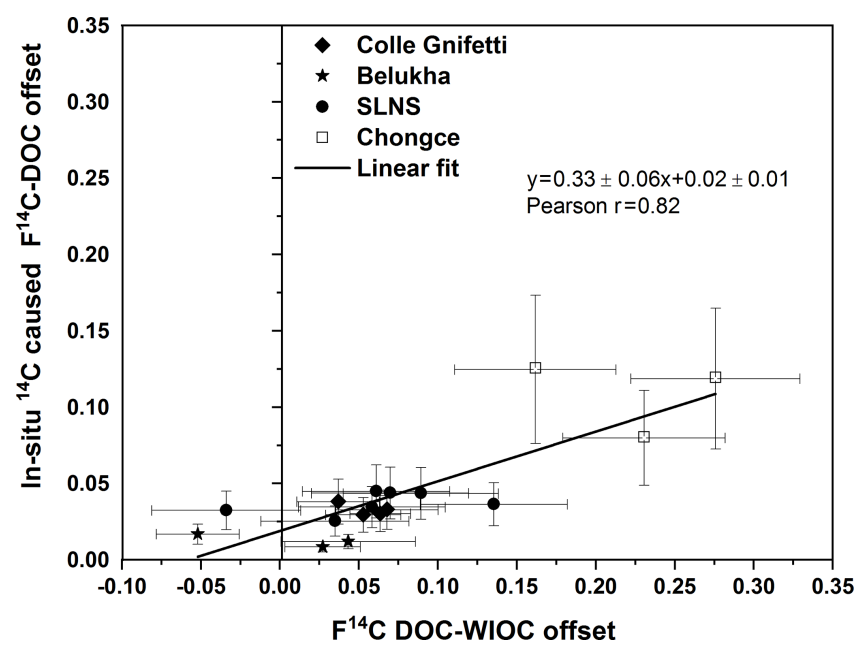

Figure 4. Estimated in situ ${ }^{14} \mathrm{C}$ offset to $\mathrm{F}^{14} \mathrm{C}$-DOC plotted against the measured offset between $\mathrm{F}^{14} \mathrm{C}$ of the DOC and WIOC fraction.

the ice can influence ${ }^{14} \mathrm{C}$ dating with WIOC in two ways: by affecting filtration through clogging of the filter and by potentially contributing ${ }^{14} \mathrm{C}$-depleted carbon from carbonate, as has been discussed in most previous studies. They all concluded that, although for dust levels typically observed in ice cores from high-elevation glaciers no significant bias is detectable for ${ }^{14} \mathrm{C}$ of WIOC, it is of concern for the elemental carbon (EC) fraction combusted at higher temperatures during OC-EC separation. EC - as well as total carbon (TC; the sum of OC and EC) - is thus not recommended to be used for radiocarbon dating (Jenk et al., 2006, 2007, 2009; Sigl et al., 2009; Uglietti et al., 2016). In any case, the carbonate removal efficiency during WIOC sample preparation was never quantified.

Here, the hypothesis that incomplete removal of carbonate may have caused the $\mathrm{F}^{14} \mathrm{C}$ DOC-WIOC offset remaining after accounting for $\mathrm{DO}^{14} \mathrm{C}$ in situ production (Sect. 4.2) was tested. Applying an isotopic-mass-balance-based model to our dataset, the carbonate removal efficiency in $\mathrm{WIO}^{14} \mathrm{C}$ samples was estimated. The $\mathrm{Ca}^{2+}$ concentration in the ice samples was thereby used as a tracer for calcium carbonate (see Supplement for details).

We find a carbonate removal procedure incomplete by around $2 \%$ (i.e. an average removal efficiency of $98 \pm 2 \%$ ) to be sufficient for explaining the remaining part of the observed $\mathrm{F}^{14} \mathrm{C}$ DOC-WIOC offset (Fig. 5). In terms of residual carbonate carbon mass on the filter, this equals $<2 \mu \mathrm{gC}$ on average (Table S2 in the Supplement). On the one hand, this is in agreement with the findings of previous studies, confirming that the potential carbonate-related bias for ${ }^{14} \mathrm{C}$ dating using WIOC is hardly detectable for ice samples with normal dust loading (effect masked by the analytical uncertainty; see Fig. S2 in the Supplement). For example, Uglietti et al. (2016) did not detect such an effect when successfully validating $\mathrm{WIO}^{14} \mathrm{C}$ dating results with ages from in- dependent methods. On the other hand, it demonstrates that a removal efficiency slightly below average for ice samples containing visibly high loading of mineral dust can already cause a notable offset (93\%-97\% for Chongce). The likely bigger particle size in such samples will affect their solubility, i.e. increase the dissolution time required in the acid treatment step. In the current procedure, this time is not adjusted accordingly (Sect. 2). Based on these results, we consider a small offset from incomplete carbonate removal to be a very likely reason contributing to the measured $\mathrm{F}^{14} \mathrm{C}$ DOC-WIOC, i.e. resulting dating offset (Fig. 5). Instead of a correction, which does not seem feasible for this effect because of large uncertainties and likely substantial site-to-site (sample-to-sample) variations, we suggest future improvement in the analytical procedure of the carbonate removal step (e.g. a slight increase in acid concentration and an increase in the reaction time).

\section{4 $\mathrm{DO}^{14} \mathrm{C}$ ages in the context of published chronologies}

In the following we discuss our new $\mathrm{DO}^{14} \mathrm{C}$ results in the context of ages from previous studies. For final calibration of ${ }^{14} \mathrm{C}$ ages, most of those earlier studies took advantage of the assumption of sequential deposition in the archive, i.e. a continuous, undisturbed and preserved sequential deposition of annual snow layers on the glacier surface. Particularly in case of relatively large analytical uncertainties compared to the age difference in the samples, the sequential deposition model can moderately constrain the probability distribution of the calibrated age range in each sample of the dataset. For consistency we applied the same calibration approach here by using the inbuilt OxCal sequence model (Ramsey, 2008). While the underlying assumption may not generally be valid for all sites and individually needs to be carefully assessed, we find no difference in the calibrated ages using the sequence model and the ages from the conventional calibration approach for all $\mathrm{DO}^{14} \mathrm{C}$ data presented in this study (Table 3). Note that no correction for a potential in situ ${ }^{14} \mathrm{C}$ bias was applied to the $\mathrm{DO}^{14} \mathrm{C}$ data used here (Sect. 4.2).

We obtained the oldest age of $\sim 21$ cal kyr BP for the bedrock ice at Belukha, indicating that this glacier is the oldest and of Pleistocene origin. This is older than the previously reported age of $\sim 11$ cal kyrBP (Table 5 , Fig. 6). The latter age was obtained for an ice core from the nearby Belukha West Plateau glacier extracted in 2003 (B03) (Aizen et al., 2016; Uglietti et al., 2016) as opposed to the 2018 core extracted from the saddle (B18) analysed in this study. Also, the according sample from B03 was from a slightly shallower depth $(0.6-0.3 \mathrm{~m}$ above bedrock) than the sample analysed from B18 in this study. The age range modelled for B03 for the same depth above bedrock (0.5$0 \mathrm{~m}$ ) is in better agreement with $\sim 28 \mathrm{cal} \mathrm{kyr} \mathrm{BP}$ and a very large uncertainty of $\sim 15 \mathrm{kyr}$ (Uglietti et al., 2016). Overall, our new age for the oldest ice at Belukha thus reason- 

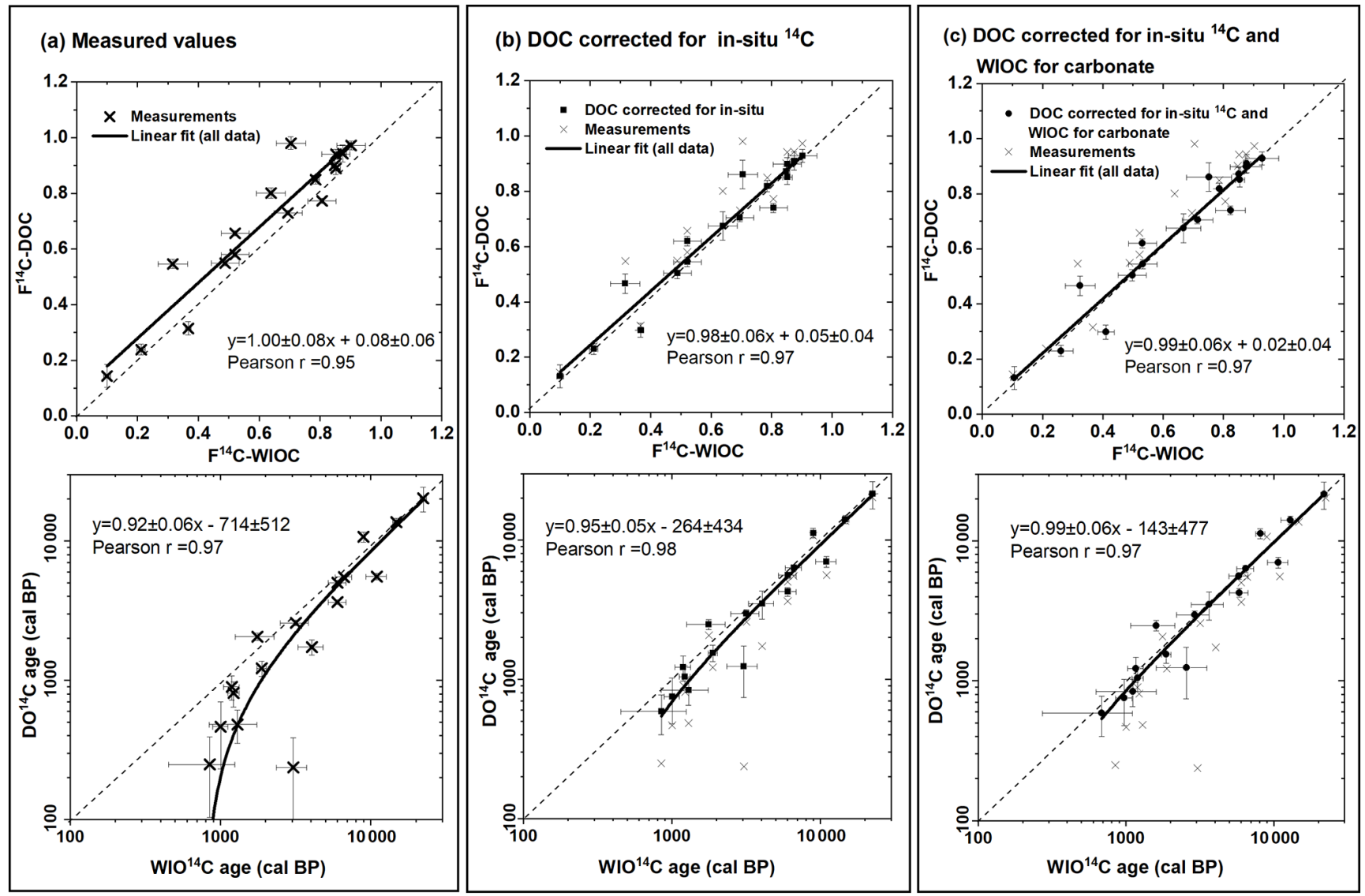

Figure 5. Scatter plots showing the correlation between $\mathrm{WIO}^{14} \mathrm{C}$ and $\mathrm{DO}^{14} \mathrm{C}$ results for all samples. In terms of $\mathrm{F}^{14} \mathrm{C}$ (top) and calibrated ages (bottom). (a) Measured values as shown in Fig. 3 but with the linear fit applied to all data (Chongce included). (b) Same as (a) but DOC ${ }^{14} \mathrm{C}$ results corrected for in situ ${ }^{14} \mathrm{C}$ contribution. (c) Same as (a) but DOC and WIOC ${ }^{14} \mathrm{C}$ results corrected for in situ ${ }^{14} \mathrm{C}$ and accounting for potentially incompletely removed carbonate, respectively. An estimated average carbonate removal efficiency of $98 \pm 2 \%$ was used here. Error bars in (a) and (b) reflect the propagated uncertainty in analysis and correction. In (b) and (c), measured values are shown as grey crosses.

ably agrees with the previous result but yields a much better constrained age, with a reduced uncertainty of $\pm 4 \mathrm{kyr}$. The two glaciers from the Tibetan Plateau (SLNS and Chongce) show very similar bottom ages of $\sim 5-6$ cal kyr BP (Fig. 6), which is in agreement with the previously reported age range of Tibetan Plateau glaciers (Hou et al., 2018). The bottom age of Chongce Core 1 determined here based on $\mathrm{DO}^{14} \mathrm{C}(5.6 \pm 0.3$ cal kyr BP $)$ is slightly younger than the previously reported bottom age in Core 2 based on $\mathrm{WIO}^{14} \mathrm{C}$ (6.3 \pm 0.3 cal kyr BP; Hou et al., 2018), which is in agreement with the findings discussed in Sect. 4.2 and 4.3. Nevertheless, our new age is still in the range of the previously estimated bottom age (Table 5, Fig. 6). The bottom-most sample of the Colle Gnifetti 2015 (CG15) core could not be dated because the small amount of ice available yielded an insufficient carbon mass of $<10 \mu \mathrm{g}$ for ${ }^{14} \mathrm{C}$ analysis. Previous $\mathrm{WIO}^{14} \mathrm{C}$ dating of a core obtained at Colle Gnifetti in 2003 (CG03) also revealed ice of Pleistocene origin, with the ice at bedrock being older than 15 cal kyr BP (Jenk et al., 2009). As expected, the age obtained in this study from a shallower depth was much younger with $1.2 \mathrm{cal} \mathrm{kyr} \mathrm{BP}$. This is in excellent agreement with the age of CG03 for a similar depth $(\sim 74 \mathrm{~m}$ below surface; Table 5, Fig. 6). We consider this to be a clear indication that the CG15 ice core did not reach bedrock.

Overall, the dating with $\mathrm{DO}^{14} \mathrm{C}$ results in ages which are in good agreement with the age ranges reported in earlier studies. Even though a contribution from in situ ${ }^{14} \mathrm{C}$ to $\mathrm{DO}^{14} \mathrm{C}$ was not considered in the comparison here, we find that the dating by the DOC fraction does not lead to significantly different results compared to dating by $\mathrm{WIO}^{14} \mathrm{C}$ or cause a different interpretation of the oldest ice still present for any of the sites. 
Table 5. $\mathrm{DO}^{14} \mathrm{C}$ dating results for near-bedrock ice compared to results from previous studies (visualized in Fig. 6).

\begin{tabular}{|c|c|c|c|c|c|}
\hline Site & Study & Core & $\begin{array}{l}\text { Dating } \\
\text { method }\end{array}$ & $\begin{array}{l}\text { Depth above bedrock } \\
\text { (m) }\end{array}$ & Age (cal BP) \\
\hline \multirow[t]{5}{*}{ Colle Gnifetti } & This study & CG15 & $\mathrm{DO}^{14} \mathrm{C}$ & $(74.3 \mathrm{~m} \text { below surface })^{\mathrm{a}}$ & $1248 \pm 144$ \\
\hline & Jenk et al. (2009) & CG03 & $\mathrm{WIO}^{14} \mathrm{C}$ & $(73.5 \mathrm{~m} \text { below surface })^{\mathrm{b}}$ & $1152 \pm 235$ \\
\hline & Jenk et al. (2009) & CG03 & Model & $(74.3 \mathrm{~m} \text { below surface })^{\mathrm{c}}$ & $1160 \pm_{170}^{140}$ \\
\hline & Jenk et al. (2009) & CG03 & $\mathrm{WIO}^{14} \mathrm{C}$ & $0.6-0$ & $>15000$ \\
\hline & Jenk et al. (2009) & CG03 & Model & Oldest ice estimate & $19100 \pm_{4500}^{4800}$ \\
\hline \multirow[t]{3}{*}{ Belukha } & This study & B18 (saddle) & $\mathrm{DO}^{14} \mathrm{C}$ & $0.5-0$ & $20393 \pm 4033$ \\
\hline & Aizen et al. (2016) & B03 (West Plateau) & $\mathrm{WIO}^{14} \mathrm{C}$ & $0.6-0.3$ & $11015 \pm 1221$ \\
\hline & Uglietti et al. (2016) & B03 (West Plateau) & Model & $0.6-0$ & $28500 \pm 16200$ \\
\hline \multirow[t]{2}{*}{ SLNS } & This study & SLNS & $\mathrm{DO}^{14} \mathrm{C}$ & $0.4-0$ & $5531 \pm 176$ \\
\hline & No previous results & & - & - & - \\
\hline \multirow[t]{3}{*}{ Chongce } & This study & Core 1 & $\mathrm{DO}^{14} \mathrm{C}$ & $0.2-0$ & $5580 \pm 295$ \\
\hline & Hou et al., 2018 & Core 2 & $\mathrm{WIO}^{14} \mathrm{C}$ & $1.2-0.8$ & $6253 \pm 277$ \\
\hline & Hou et al., 2018 & Core 2 & Model & Oldest ice estimate & $9000 \pm \pm_{3600}^{7900}$ \\
\hline
\end{tabular}

${ }^{a}$ Precise bedrock depth unknown at this coring site. ${ }^{b}$ Sampled depth being closest to depth sampled in this study (CG03 and CG15 drill sites only $16 \mathrm{~m}$ apart). ${ }^{\mathrm{C}}$ Modelled age at same depth as sampled in this study.

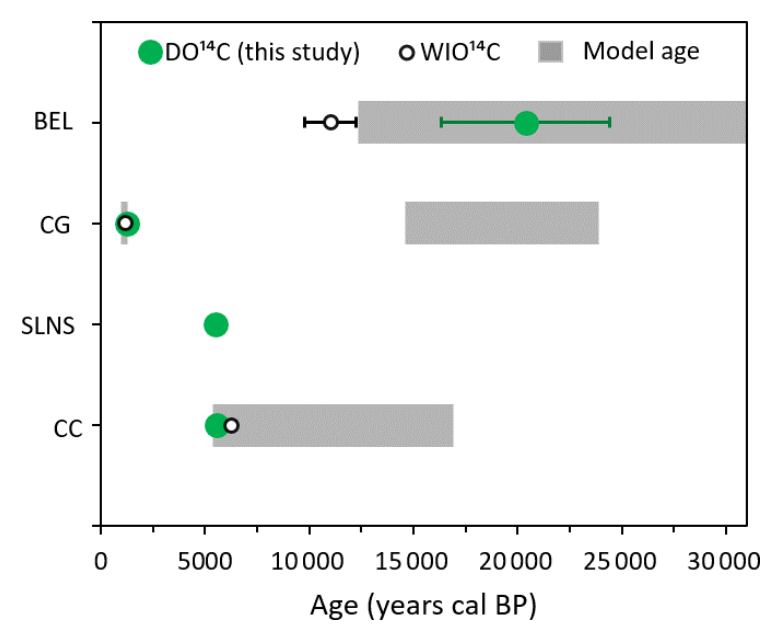

Figure 6. Comparison of our $\mathrm{DO}^{14} \mathrm{C}$ ages (not corrected for in situ) with dating results from previous studies if available. For the four sites of Belukha (BEL), Colle Gnifetti (CG), Shule Nanshan (SLNS) and Chongce (CC), $\mathrm{DO}^{14} \mathrm{C}$ ages (green) and previously reported $\mathrm{WIO}^{14} \mathrm{C}$ ages (open circles) for similar sampling depths are shown. Grey bars indicate previously modelled, ${ }^{14} \mathrm{C}$-based bedrock age estimates (additionally for CG the modelled age for the bottom sampling depth of this study). Previously published data are from Uglietti et al. (2016) (BEL West Plateau), Jenk et al. (2009) (CG) and Hou et al. (2018) (CC). See Table 5 for underlying data and details.

\section{Conclusions}

In this study, we evaluated and successfully validated the $\mathrm{DO}^{14} \mathrm{C}$ dating technique by direct comparison of dating results with the well-established $\mathrm{WIO}^{14} \mathrm{C}$ method using par- allel ice samples. Achieving this goal was not only analytically demanding but also highly challenging due to the very limited availability of the sampling material, requiring ice in rather large quantities and spanning a wide range of ages. The obtained $\mathrm{DO}^{14} \mathrm{C}$ ages for four different Eurasian glaciers, ranging from $0.2 \pm 0.2$ to $20.3 \pm$ 4.1 cal kyr BP, agreed well with the respective $\mathrm{WIO}^{14} \mathrm{C}$ ages $(0.8 \pm 0.4$ to $22.4 \pm 1.1$ cal kyr BP $)$ and with previously published chronologies from these ice core sites. This underlines the great potential for applying $\mathrm{DO}^{14} \mathrm{C}$ analysis for ice core dating. With this new method, an average dating uncertainty of around \pm 200 years was achieved for samples with an absolute carbon mass of $>20 \mu \mathrm{g}$ and ages up to $\sim 6 \mathrm{kyr}$. For DOC concentrations observed in this study, an initial ice mass of about $250 \mathrm{~g}$ was required. Our data confirmed previous results that concentrations of pre-industrial DOC are higher by about a factor 2 compared to WIOC concentrations in high alpine ice cores. This shows that the required ice mass to achieve similar precision is reduced by at least a factor of 2 for ${ }^{14} \mathrm{C}$ dating when using the DOC instead of the WIOC fraction. Accordingly, an improvement in precision can be achieved for the same sample mass. Compared to WIOC, a downside of using the DOC fraction for ${ }^{14} \mathrm{C}$ dating is a more demanding and time-consuming extraction procedure. In addition, because of its higher solubility and a related higher mobility of DOC in case of meltwater formation, this fraction is only applicable for dating ice which had been cold throughout its "lifetime". Beneficial compared to WIOC, there is no potential for a dating bias by carbonates of mineral dust for $\mathrm{DO}^{14} \mathrm{C}$. However, our results confirm previously suggested potential dating biases from in situ ${ }^{14} \mathrm{C}$ causing $\mathrm{DO}^{14} \mathrm{C}$ dates to shift towards younger ages. While 
we find the effect to be small (at the level of analytical uncertainty), it may become significant for $\mathrm{DO}^{14} \mathrm{C}$ dating of ice samples from sites of exceptionally high altitude, for example, experiencing low annual net accumulation rates in addition. For such sites, a reasonably accurate correction to account for the age bias seems feasible according to our results, although at the cost of an increase in the final dating uncertainty. Nevertheless, we think this new dating method has great potential to open up new fields for radiocarbon dating of ice, for example from remote regions, where concentrations of organic impurities in the ice are particularly low.

Data availability. The data are provided in the tables.

Supplement. The supplement related to this article is available online at: https://doi.org/10.5194/tc-15-1537-2021-supplement.

Author contributions. LF and TS performed ${ }^{14} \mathrm{C}$ analysis. LF, TMJ and MS wrote the manuscript. All authors, including SH, contributed to the discussion of the results. TMJ assisted and partly developed the modelling. MS designed the study.

Competing interests. The authors declare that they have no conflict of interest.

Acknowledgements. We thank Johannes Schindler for his great work in designing and building the DOC extraction system and the two drilling teams on Colle Gnifetti and Belukha for collecting high-quality ice cores. We acknowledge funding from the Swiss National Science Foundation (SNF) for the Sinergia project Paleo fires from high-alpine ice cores (grant no. CRSII2_154450), which allowed ice core drilling on Colle Gnifetti and Belukha; for the project Radiocarbon dating of glacier ice (grant no. 200021_126515); and for the project Reconstruction of pre-industrial to industrial changes of organic aerosols from glacier ice cores (grant no. 200021_182765). We acknowledge the funding from the National Natural Science Foundation of China (grant nos. 91837102, 41830644) for the Tibetan ice core drilling. We dedicate this study to Alexander Zapf, who died tragically while climbing in the Swiss Alps before he could fulfil his dream of ice dating with $\mathrm{DO}^{14} \mathrm{C}$.

Financial support. This research has been supported by the Swiss National Science Foundation (grant nos. CRSII2_154450, 200021_126515 and 200021_182765) and the National Natural Science Foundation of China (grant nos. 91837102 and 41830644).

Review statement. This paper was edited by Joel Savarino and reviewed by two anonymous referees.

\section{References}

Agrios, K., Salazar, G., Zhang, Y.-L., Uglietti, C., Battaglia, M., Luginbühl, M., Ciobanu, V. G., Vonwiller, M., and Szidat, S.: Online coupling of pure $\mathrm{O}_{2}$ thermo-optical methods $-{ }^{14} \mathrm{C}$ AMS for source apportionment of carbonaceous aerosols, Nucl. Instrum. Meth. B, 361, 288-293, https://doi.org/10.1016/j.nimb.2015.06.008, 2015.

Agrios, K., Salazar, G., and Szidat, S.: A Continuous-Flow Gas Interface of a Thermal/Optical Analyzer With ${ }^{14} \mathrm{C}$ AMS for Source Apportionment of Atmospheric Aerosols, Radiocarbon, 59, 921932, https://doi.org/10.1017/RDC.2016.88, 2017.

Aizen, E. M., Aizen, V. B., Takeuchi, N., Mayewski, P. A., Grigholm, B., Joswiak, D. R., Nikitin, S. A., Fujita, K., Nakawo, M., and Zapf, A.: Abrupt and moderate climate changes in the mid-latitudes of Asia during the Holocene, J. Glaciol., 62, 411439, https://doi.org/10.1017/jog.2016.34, 2016.

Bolzan, J. F.: Ice flow at the Dome $\mathrm{C}$ ice divide based on a deep temperature profile, J. Geophys. Res.-Atmos., 90, 8111-8124, https://doi.org/10.1029/JD090iD05p08111, 1985.

Fang, L., Schindler, J., Jenk, T., Uglietti, C., Szidat, S., and Schwikowski, M. J. R.: Extraction of Dissolved Organic Carbon from Glacier Ice for Radiocarbon Analysis, Radiocarbon, 61, 681-694, https://doi.org/10.1017/RDC.2019.36, 2019.

Fang L., Cao F., Jenk T. M., Vogel A. L., Zhang Y. L., Wacker L., Salazar G., Szidat S., and Schwikowski M.: Enhancement of carbonaceous aerosol during the 20th century by anthropogenic activities: insights from an Alpine ice core, in preparation, 2021.

Gavin, D. G.: Estimation of inbuilt age in radiocarbon ages of soil charcoal for fire history studies, Radiocarbon 43, 27-44, 2001.

Gordon, M. S., Goldhagen, P., Rodbell, K. P., Zabel, T. H., Tang, H. H. K., Clem, J. M., and Bailey, P. Measurement of the flux and energy spectrum of cosmic-ray induced neutrons on the ground, IEEE T. Nucl. Sci., 51, 3427-3434, 2004.

Hoffmann, H., Preunkert, S., Legrand, M., Leinfelder, D., Bohleber, P., Friedrich, R., and Wagenbach, D.: A New Sample Preparation System for Micro-14C Dating of Glacier Ice with a First Application to a High Alpine Ice Core from CG (Switzerland), Radiocarbon, 60, 517-533. https://doi.org/10.1017/RDC.2017.99, 2018.

Hoffmann H. M.: Micro radiocarbon dating of the particulate organic carbon fraction in Alpine glacier ice: method refinement, critical evaluation and dating applications, thesis, Ruperto-Carola University of Heidelberg, https://doi.org/10.11588/heidok.00020712, 2016.

Hou, S., Jenk, T. M., Zhang, W., Wang, C., Wu, S., Wang, Y., Pang, H., and Schwikowski, M.: Age ranges of the Tibetan ice cores with emphasis on the Chongce ice cores, western Kunlun Mountains, The Cryosphere, 12, 2341-2348, https://doi.org/10.5194/tc-12-2341-2018, 2018.

Hou, S., Zhang, W., Fang, L., Jenk, T. M., Wu, S., Pang, H., and Schwikowski, M.: Brief Communication: New evidence further constraining Tibetan ice core chronologies to the Holocene, The Cryosphere Discuss. [preprint], https://doi.org/10.5194/tc-2020225, in review, 2020.

Jenk, T. M., Szidat, S., Schwikowski, M., Gäggeler, H. W., Brütsch, S., Wacker, L., Synal, H.-A., and Saurer, M.: Radiocarbon analysis in an Alpine ice core: record of anthropogenic and biogenic contributions to carbonaceous aerosols in the past (1650-1940), Atmos. Chem. Phys., 6, 5381-5390, https://doi.org/10.5194/acp6-5381-2006, 2006. 
Jenk, T. M., Szidat, S., Schwikowski, M., Gäggeler, H., Wacker, L., Synal, H.-A., and Saurer, M.: Microgram level radiocarbon $\left({ }^{14} \mathrm{C}\right)$ determination on carbonaceous particles in ice, Nucl. Instrum. Meth. B, 259, 518-525, https://doi.org/10.1016/j.nimb.2007.01.196, 2007.

Jenk, T. M., Szidat, S., Bolius, D., Sigl, M., Gaeggeler, H. W., Wacker, L., Ruff, M., Barbante, C., Boutron, C. F., and Schwikowski, M.: A novel radiocarbon dating technique applied to an ice core from the Alps indicating late Pleistocene ages, J. Geophys. Res.-Atmos., 114, D14305, https://doi.org/10.1029/2009JD011860, 2009.

Lal, D., Nishiizumi, K., and Arnold, J. R.: In situ cosmogenic ${ }^{3} \mathrm{H}$, ${ }^{14} \mathrm{C}$, and ${ }^{10} \mathrm{Be}$ for determining the net accumulation and ablation rates of ice sheets, J. Geophys. Res.-Sol. Ea., 92.B6, 4947-4952, 1987.

Lal, D., Jull, A. T., Burr, G., and Donahue, D.: Measurements of in situ ${ }^{14} \mathrm{C}$ concentrations in Greenland Ice Sheet Project 2 ice covering a 17-kyr time span: Implications to ice flow dynamics, J. Geophys. Res.-Oceans, 102, 26505-26510, https://doi.org/10.1029/96JC02224, 1997.

Legrand, M., Preunkert, S., Schock, M., Cerqueira, M., Kasper-Giebl, A., Afonso, J., Pio, C., Gelencsér, A., and Dombrowski-Etchevers, I.: Major 20th century changes of carbonaceous aerosol components (EC, WinOC, DOC, HULIS, carboxylic acids, and cellulose) derived from Alpine ice cores, J. Geophys. Res.-Atmos., 112, D23S11, https://doi.org/10.1029/2006JD008080, 2007.

Legrand, M., Preunkert, S., Jourdain, B., Guilhermet, J., Faïn, X., Alekhina, I., and Petit, J. R.: Water-soluble organic carbon in snow and ice deposited at Alpine, Greenland, and Antarctic sites: a critical review of available data and their atmospheric relevance, Clim. Past, 9, 2195-2211, https://doi.org/10.5194/cp-92195-2013, 2013.

Licciulli, C., Bohleber, P., Lier, J., Gagliardini, O., Hoelzle, M., and Eisen, O.: A full Stokes ice-flow model to assist the interpretation of millennial-scale ice cores at the high-Alpine drilling site Colle Gnifetti, Swiss/Italian Alps, J. Glaciol., 66, 35-48, https://doi.org/10.1017/jog.2019.82, 2020.

May, B., Wagenbach, D., Hoffmann, H., Legrand, M., Preunkert, S., and Steier, P.: Constraints on the major sources of dissolved organic carbon in Alpine ice cores from radiocarbon analysis over the bomb-peak period, J. Geophys. Res.-Atmos., 118, 33193327, https://doi.org/10.1002/jgrd.50200, 2013.

May, B. L.: Radiocarbon microanalysis on ice impurities for dating of Alpine glaciers, PhD thesis, University of Heidelberg, Heidelberg, Germany, 127 pp., 2009.

Minguillón, M. C., Perron, N., Querol, X., Szidat, S., Fahrni, S. M., Alastuey, A., Jimenez, J. L., Mohr, C., Ortega, A. M., Day, D. A., Lanz, V. A., Wacker, L., Reche, C., Cusack, M., Amato, F., Kiss, G., Hoffer, A., Decesari, S., Moretti, F., Hillamo, R., Teinilä, K., Seco, R., Pe Nuelas, J., Metzger, A., Schallhart, S., Müller, M., Hansel, A., Burkhart, J. F., Baltensperger, U., and Prévôt, A. S. H.: Fossil versus contemporary sources of fine elemental and organic carbonaceous particulate matter during the DAURE campaign in Northeast Spain, Atmos. Chem. Phys., 11, 1206712084, https://doi.org/10.5194/acp-11-12067-2011, 2011.

Mohn, J., Szidat, S., Fellner, J., Rechberger, H., Quartier, R., Buchmann, B., and Emmenegger, L.: Determination of biogenic and fossil $\mathrm{CO}_{2}$ emitted by waste incineration based on ${ }^{14} \mathrm{CO}_{2}$ and mass balances, Bioresource Technol., 99, 6471-6479, 2008.

Nye, J.: On the theory of the advance and retreat of glaciers, Geophys. J. Int., 7, 431-456, 1963.

Petrenko, V. V., Severinghaus, J. P., Smith, A. M., Riedel, K., Baggenstos, D., Harth, C., Orsi, A., Hua, Q., Franz, P., Takeshita, Y., Brailsford, G., Weiss, R. F., Buizert, C., Dickson, A., and Schaefer, H.: High-precision ${ }^{14} \mathrm{C}$ measurements demonstrate production of insitu cosmogenic ${ }^{14} \mathrm{CH}_{4}$ and rapid loss of insitu cosmogenic ${ }^{14} \mathrm{CO}$ in shallow Greenland firn, Earth Planet. Sc. Lett., 365, 190-197, 2013.

Ramsey, C. B.: Deposition models for chronological records, Quaternary Sci. Rev., 27, 42-60, https://doi.org/10.1016/j.quascirev.2007.01.019, 2008.

Ramsey, C. B.: Methods for summarizing radiocarbon datasets, Radiocarbon, 59, 1809-1833, https://doi.org/10.1017/RDC.2017.108, 2017.

Reimer, P. J., Bard, E., Bayliss, A., Beck, J. W., Blackwell, P. G., Ramsey, C. B., Buck, C. E., Cheng, H., Edwards, R. L., Friedrich, M., Grootes, P., Guilderson, T., Haflidason, H., Hajdas, I., Hatté, C., Heaton, T., Hoffmann, D. L., Hogg, A. G., Hughen, K. A., Felix Kaiser, K., Kromer, B., Manning, S. W., Niu, M., Reimer, R. W., Richards, D. A., Scott, E. M., Southon, J. R., Staff, R. A., Turney, C. S., and van der Plicht, J.: IntCal13 and Marine13 radiocarbon age calibration curves 0-50,000 years cal BP, Radiocarbon, 55, 1869-1887, https://doi.org/10.2458/azu_js_rc.55.16947, 2013.

Ruff, M., Wacker, L., Gäggeler, H., Suter, M., Synal, H.A., and Szidat, S.: A gas ion source for radiocarbon measurements at $200 \mathrm{kV}$, Radiocarbon 49, 307-314, https://doi.org/10.1017/S0033822200042235, 2007.

Sigl, M., Jenk, T. M., Kellerhals, T., Szidat, S., Gäggeler, H. W., Wacker, L., Synal, H.-A., Boutron, C., Barbante, C., and Gabrieli, J.: Towards radiocarbon dating of ice cores, J. Glaciol., 55, 985-996, https://doi.org/10.3189/002214309790794922, 2009.

Sigl, M., Abram, N. J., Gabrieli, J., Jenk, T. M., Osmont, D., and Schwikowski, M.: 19th century glacier retreat in the Alps preceded the emergence of industrial black carbon deposition on high-alpine glaciers, The Cryosphere, 12, 3311-3331, https://doi.org/10.5194/tc-12-3311-2018, 2018.

Smith, A., Levchenko, V., Etheridge, D., Lowe, D., Hua, Q., Trudinger, C., Zoppi, U., and Elcheikh, A.: In search of in-situ radiocarbon in Law Dome ice and firn, Nucl. Instrum. Meth. B, 172, 610-622, https://doi.org/10.1016/S0168-583X(00)00280-9, 2000.

Steier, P., Fasching, C., Mair, K., Liebl, J., Battin, T., Priller, A., and Golser, R.: A new UV oxidation setup for small radiocarbon samples in solution, Radiocarbon, 55, 373-382, https://doi.org/10.2458/azu_js_rc.55.16368, 2013.

Stuiver, M. and Polach, H. A.: Discussion reporting of ${ }^{14} \mathrm{C}$ data, Radiocarbon, 19, 355-363, 1977.

Synal, H.-A., Stocker, M., and Suter, M.: MICADAS: a new compact radiocarbon AMS system, Nucl. Instrum. Meth. B, 259, 713, https://doi.org/10.1016/j.nimb.2007.01.138, 2007.

Szidat, S., Salazar, G. A., Vogel, E., Battaglia, M., Wacker, L., Synal, H.-A., and Türler, A.: ${ }^{14} \mathrm{C}$ analysis and sample preparation at the new Bern Laboratory for the Analysis of 
Radiocarbon with AMS (LARA), Radiocarbon, 56, 561-566, https://doi.org/10.2458/56.17457, 2014.

Thompson, L. G., Tandong, Y., Davis, M. E., MosleyThompson, E., Mashiotta, T. A., Lin, P.-N., Mikhalenko, V. N., and Zagorodnov, V. S. J. A. o. G.: Holocene climate variability archived in the Puruogangri ice cap on the central Tibetan Plateau, Ann. Glaciol., 43, 61-69, https://doi.org/10.3189/172756406781812357, 2006.

Uglietti, C., Zapf, A., Jenk, T. M., Sigl, M., Szidat, S., Salazar, G., and Schwikowski, M.: Radiocarbon dating of glacier ice: overview, optimisation, validation and potential, The Cryosphere, 10, 3091-3105, https://doi.org/10.5194/tc-10-30912016, 2016.

Van de Wal, R., Van Roijen, J., Raynaud, D., Van der Borg, K., De Jong, A., Oerlemans, J., Lipenkov, V., and Huybrechts, P.: From ${ }^{14} \mathrm{C} /{ }^{12} \mathrm{C}$ measurements towards radiocarbon dating of ice, Tellus B 46, 91-102, https://doi.org/10.3402/tellusb.v46i2.15755, 1994.

Wacker, L., Fahrni, S. M., Hajdas, I., Molnar, M., Synal, H. A., Szidat, S., and Zhang, Y. L.: A versatile gas interface for routine radiocarbon analysis with a gas ion source, Nucl. Instrum. Meth. B, 294, 315-319, https://doi.org/10.1016/j.nimb.2012.02.009, 2013.
Woon, D. E.: Modeling gas-grain chemistry with quantum chemical cluster calculations. I. Heterogeneous hydrogenation of $\mathrm{CO}$ and $\mathrm{H}_{2} \mathrm{CO}$ on icy grain mantles, Astrophys. J., 569, 541-548, 2002.

Yankwich, P. E., Rollefson, G. K., and Norris, T. H.: Chemical Forms Assumed by $\mathrm{C}^{14}$ Produced by Neutron Irradiation of Nitrogenous Substances, J. Chem. Phys., 14, 131-140, 1946.

Zhang, Y., Yao, Y., Wang, X., Liu, Y., and Piao, S.: Mapping spatialdistribution of forest age in China, Earth Space Sci., 4, 108116, https://doi.org/10.1002/2016EA000177, 2017.

Zhang, Y. L., Perron, N., Ciobanu, V. G., Zotter, P., Minguillón, M. C., Wacker, L., Prévôt, A. S. H., Baltensperger, U., and Szidat, S.: On the isolation of OC and EC and the optimal strategy of radiocarbon-based source apportionment of carbonaceous aerosols, Atmos. Chem. Phys., 12, 10841-10856, https://doi.org/10.5194/acp-12-10841-2012, 2012. 